\title{
Education and Work Preferences of African Diaspora Women in the United States
}

\author{
by Dorothy K. Williamson-Ige, School of Speech Communication, Bowling Green \\ State University, Ohio
}

Contemporary women from technological cultures are often perceived as self- rather than family- or relationship-oriented. ${ }^{1}$ Whether true or false, this perception creates problems in communication between males and females in the United States, ${ }^{2}$ especially in communities where black women grounded in African-world views attempt to respond to conflicting western cultural orientations. ${ }^{3}$ Issues of marriage, child-care, economics, employment, career advancement, and race relations have often contributed to the nexus of confusion surrounding the education and work of black women in a highly industrialised society.

My purpose is to assess the effect of education on preferences for paid employment outside the home among black females in the United States who are members of the African diaspora, and hence scattered far from their descendants and original homes. Additionally, I shall relate my findings to the point made by J. T. Wood, that communication tends to create, bind, or shatter familial relationships. ${ }^{4}$

\section{Background}

Three basic areas of research are relevant to this discussion. First of all, although several scholars have noted that the education of black women correlates highly with occupation and income, ${ }^{5}$ as D. D. Knudsen points out, [while] the female's alternatives to maternity and homemaking have declined in appeal and significance, most women pursue educational goals with less dedication than men, are thus less well prepared for the competitive market and receive lower levels of economic rewards. ${ }^{6}$

Secondly, the actual participation of African-American women in the labour force provides clues to their attitudes towards working for pay outside the home. Whether or not black women in the United States wish to work is largely a matter of fantasy - most must in order to survive in a dignified manner. ${ }^{7} \mathrm{C}$. Bird

1 F. S. Yousef, 'North Americans in the Middle East: aspects of the roles of friendliness, religion, and women in cross-cultural relations', in L. A. Samovar and R. E. Porter (eds.), Intercultural Communication: a reader (Belmont, California, 1982), pp. 93-8.

2 Hamida and Haig Bosmajian (eds.), This Great Argument: the rights of women (Reading, Mass., 1972), and M. Wallace, Black Macho and the Myth of the Superwoman (New York, 1979).

${ }^{3}$ R. Staples, The Black Woman in America: sex, marriage, and the family (Chicago, 1973).

- J. T. Wood, 'Communication and Relational Culture: bases for the study of human relationships', in Communication Quarterly (Philadelphia), 3o, 2, 1982, pp. 75-84.

${ }^{5}$ P. A. Wallace, Black Women in the Labor Force (Cambridge, Mass., 1980), and D. D. Knudsen, 'The Declining Status of Women: popular myths and the failure of functionalist thought', in Bosmajians (eds.), op. cit.

- Knudsen, loc. cit. p. 160 . This conclusion is corroborated by C. Bird, What Women Want (New York, 1977), and P. M. Wallace, op. cit.

' E. Green, 'Representative Edith Green Speaks in Support of the Equal Rights Amendment', in Bosmajians (eds.), op. cit. pp. 237-42; and C. B. Leggon, 'Black Female Professionals: dilemmas, contradictions of statutes', in L. Rodgers-Rose (ed.), The Black Woman (Beverly Hills, I980), pp. $189^{-202}$. 
has stated that although minority females 'are more apt to be in the labor force than white women...they are almost twice as likely to be unemployed and to suffer more job loss when the economy is depressed', ${ }^{1}$ while P. M. Wallace concludes that 'the earnings of black women workers are the lowest of all workers in the labor market'. ${ }^{2}$

In a third body of literature, several writers have analysed rôles of African-American women and family relations. J. Brown has indicated that paid work is due to necessity, not for purposes of the self-serving materialism which is contradictory to pre-colonial West African mores. ${ }^{3}$ At the same time, C. B. Leggon and K. F. Schaffer have found that black women tend to agree with black men that their chief responsibility should be in the home. ${ }^{4}$ African-American males appear to have little ambivalence about women working, and tend to view paid employment as providing the succour which will be an asset in strengthening family unity rather than a liability. Similarly, B. Bettelheim has indicated that women who have fulfilled their educational or career goals have better relationships with their spouses and children than those who are tension-ridden and unfulfilled. ${ }^{5}$ Schaffer has also point out that black women 'have a history of combining outside employment and motherhood. Raising children is still a major sex role of black women, and the role of mother is central to the black woman's definition of self' ${ }^{6} \mathrm{~J}$. Hale ventures further to suggest that motherhood for black women is "possibly even more important than the role of wife'.?

There is considerable evidence that African-American women have had to exhibit more aplomb and independence regarding work and economics than is found in traditional West African cultures, where they could rely extensively on the collective responsibility of the extended family. ${ }^{8}$ Race relations in the United States, which historically left many black males with little education, inferior jobs, and economic instability, have forced black women to exhibit extraordinary sinew. Several authors have noted that the necessary adaptation needed for their survival (with their children) in the United States has inappropriately earned these women a reputation for exhibiting hubris and the label of domineering black matriarchs. ${ }^{9}$ According to Schaffer:

both black and white cultures have often accepted the stereotype of black matriarchy, with the result that black women have sometimes been made the scapegoats for the oppression that the white culture has perpetuated on black men. ${ }^{10}$

Technology has been cited as having a tremendous impact in the United

1 Bird, op. cit. p. I 18.

2 P. A. Wallace, op. cit. p. $5^{8}$.

${ }^{3}$ J. Brown, 'Liberation Struggle Generates Tension on Race, Sex Issues', in Bosmajians (eds.), op. cit. p. 266.

4 Leggon, loc. cit., and K. F. Schaffer, Sex Roles and Human Behavior (Cambridge, Mass., $198 \mathrm{I}$ ).

s B. Bettelheim, 'Growing Up Female', in Bosmajians (eds.), op. cit. p. I 10.

- Schaffer, op. cit. p. 290.

7 J. Hale, 'The Black Woman and Child Rearing', in Rodgers-Rose (ed.), op. cit. p. 80.

8 J. C. Condon and F. S. Yousef, An Introduction to Intercultural Communication (Indianapolis, I 98 I), Hale, loc. cit. pp. $179-88$, Schaffer, op. cit., and Staples, op. cit.

- R. Staples, 'The Myth of Black Macho: a response to angry black feminists', in The Black Scholar (Sausalito, Calif.), March-April 1979, pp. 24-33; see also Hale, loc. cit. and Schaffer, op. cit.

10 Schaffer, op. cit. p. 318. 
States on the work attitudes and family relationships of black women. ${ }^{1}$ Along with increased scientific knowledge and socio-economic advancements have come significant changes in society: white-collar jobs requiring little manual labour, thereby helping to equalise the work rôles of both sexes; increased leisure time allowing women to seek educational goals; improved health leading to an increased life span; later marriages, with fewer children and higher rates of divorce; and rising standards of living, not to mention inflation, necessitating two pay-cheque families. Thus, education, history, race, and modern science have all had an impact on African-American family relations in the United States.

\section{* * *}

Past research adequately assesses the current situation in regard to the education, work, and familial relations of black women in the United States, rather than indicating what they want. Since the studies cited earlier agree that most African-American women must work to survive in a dignified manner in the United States, I wanted to know whether they would still choose paid employment outside the home, if given a choice, and whether their preferences would be directly affected by their level of education. Specifically, I formulated the following hypothesis:

Among black women of $W$ est African descent in the United States, post-secondary educated females will prefer paid employment outside the home significantly more than secondary educated females.

\section{Method}

My sample consisted of 148 African-American women: 82 with secondary education (i.e. those who had received schooling from eighth to twelfth grades) and 66 with post-secondary higher education, largely from central and north-western Ohio. In order to provide a representative cross-section of the general population, those interviewed ranged from domestic workers to business executives and lawyers, with an upper age limit of 65 .

A response sheet was constructed in order to maintain written records of oral responses, prefaced by an age range, level of education, and race. The opinions of the respondents were collected through interviews, at random, and recorded by two African-American females who had previously carefully reviewed the written and verbal instructions.

Results

All the respondents were asked the following question: 'If given a choice, do you actually wish to maintain paid employment outside the home much of your life'? Only 2 were undecided. Of the 80 who answered 'Yes', 38 were secondary and 42 were post-secondary educated; of the 66 who answered 'No', 43 were secondary and 23 were post-secondary educated. These figures were analysed by using Yate's correction for chi-square tests, ${ }^{2}$ as follows:

\footnotetext{
' Bird, op. cit. and B. W. and R. G. Eakins, Sex Differences in Human Communication (Boston, $1978)$.

2 J. L. Bruning and B. L. Kintz, Computational Handbook of Statistics, 2nd edn. (Glenview, Ill., 1977), p. 232.
} 


$$
\begin{aligned}
X^{2} & =146 \frac{\left[\left|38(23)-4^{2}(43)\right|-\frac{146}{2}\right]^{2}}{80(66)(8 I)(65)} \\
& =146 \frac{[|374-1806|-73]^{2}}{27,799,200}=\frac{146[932-73]^{2}}{27,799,200} \\
& =\frac{146[737,88 \mathrm{I}]}{27,799,200}=\frac{107,730,626}{27,799,200}=3 \cdot 88 \\
X^{2} & (0 \cdot 05, \mathrm{I})=3 \cdot 840 .
\end{aligned}
$$

These calculations show that a significantly greater number of AfricanAmerican females with post-secondary education voiced a desire for paid work outside the home than those with only secondary education. In other words, the hypothesis was accepted, thereby corroborating similar conclusions in regard to black females of the United States. ${ }^{1}$

\section{Discussion}

It is understandable that African-American women may not wish to accept the unattractive kind of work usually offered to those who have no postsecondary training. These women tend to view employment not as a means of liberation, but as captivity, since their work often includes unrewarding tasks, as well as sexual harrassment and exploitative situations as domestic servants. $^{2}$ The desire for paid employment outside the home is equally comprehendible for females with a higher level of education, since the work situation is usually more fulfilling, even though it is often service-oriented and/or for lower wages vis-à-vis those received by males or white women.

Black females with post-secondary training have developed independence which comes with education, race problems, and work in America. At the same time, any move to damage family relations appears to be the antithesis of African-American female motivations. Those who juggle education, motherhood, and outside employment may be the most committed of any group to the continuity of the black family in the United States. The liberation of African-American women does not appear to come from a foreign ideology. Co-operative child-care among those with different work schedules - similar to the extended family concept - and the commitment of black women to their children, attest to the fact that liberation, for black women at any educational level, does not mean organising against the family.

In order to balance education, family, and work, an equalisation of male/female rôles in the black family is necessary. This is harmonious with indigenous familial relationships in which work is shared.$^{3}$ At the same time, it represents a departure from West African tradition, since the quality of work will be different for men and women as they undertake equal rôles inside and outside the home. As M. Furay has noted of both western and non-western cultures, 'In no society do males and females do the same thing', and in regard to gender behaviour, 'It need not be the same, but it should be equal'.4

1 Bosmajians (eds.), op. cit.; Leggon, loc. cit.; Schaffer, op. cit.; and P. A. Wallace, op. cit.

${ }^{2}$ G. Lerner (ed.), Black Women in White America: a documentary history (New York, 1972).

3 Bettelheim, loc. cit. p. 116, and Schaffer, op. cit.

4 M. Furay, 'Metropolitan Detroit AFL-CIO Council', in Bosmajians (eds.), op. cit. p. 226. 
African-American female strength and patience can be incorporated not only in the home, but can be used outside for the benefit of society as a whole.

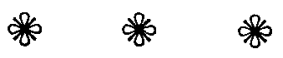

We need to know more about the rôle of black women and their familial relations, both nationally and internationally. Comparisons between secondary and post-secondary respondents of both genders in the United States, and between those displaced from other environments should present interesting findings. Other studies could yield insights not only into the barriers that inhibit effective communication between males and females, but also into the complex problems faced by black women, whether perceived or real, in regard to their education and work preferences in weakening or strengthening family relationships in western and non-western cultures. This information could prove helpful to people the world over as they determine directions which will homogenise educational and technological advancements with humanitarianism in the light of their unique cultures, economics, and history. 